DOI 10.17150/978-5-7253-3001-4.45

И.С. ЦЫРЕМПИЛОВА

УДК $719.67+271.22(571.54)$

ББК $79.05+86.372 .24$

\title{
ПРАВОСЛАВНЫЕ КУЛЬТОВЫЕ ОБЪЕКТЫ НА ТЕРРИТОРИИ БУРЯТИИ: ОПЫТ СОХРАНЕНИЯ И СОВРЕМЕННОЕ СОСТОЯНИЕ
}

В статье анализируется опыт сохранения и современное состояние православных храмов Бурятии. Эти вопросы рассматриваются на примере Посольского Спасо-Преображенского монастыря, ансамбля Селенгинского Троицкого монастыря, Одигитриевского Собора г. Улан-Удэ, Собора Троицы и Воскресенской церкви г. Кяхта, являющихся объектами культурного наследия федерального значения.

Ключевые слова: Русская православная церковь, культурное наследие, монастырь, собор, церковь, реставрация, музеефикация. 


\section{ORTHODOX CULT MONUMENTS ON THE TERRITORY OF THE REPUBLIC OF BURYATIA: EXPERIENCE OF CONSERVATION AND MODERN CONDITION}

The article analyzes experience of conservation and modern condition of the Orthodox churches of Buryatia. These questions are examined on the example of the Orthodox monasteries and churches, which are the objects of cultural heritage of the federal importance such as Posol'sk SpasoPreobrazhensky monastery, the group of Holy Trinity Selenga monastery, Odigitria Cathedral in Ulan-Ude, Trinity Cathedral in Kyakhta, Resurrection Cathedral in Kyakhta.

Keywords: Russian Orthodox Church, cultural heritage, monastery, cathedral, church, conservation, museumification.

Уникальность и своеобразие культурного пространства Республики Бурятия подчеркивается устойчивым взаимодействием и взаимовлиянием религиозных конфессий, которое привело к синтезу разнородных традиций и укладов. К особенным и ярким проявлениям этого взаимодействия относятся памятники культовой архитектуры. Они, являясь результатом сложного технического и художественного процесса, выступают как комплексный и многогранный источник. При этом они обладают не только свойством хранить и передавать инфрормацию, но и исключительным эффректом эмоционального воздействия. Так, составители «Свода объектов культурного наследия Республики Бурятия» подчеркивают, что «белокаменные своды православных храмов, затейливое узорчатое кружево деревянных домов, яркие росписи старообрядческих изб, буддийские дацаны, многоярусные с коническим завершением субурганы гармонично вписываются в окружающую нас природу» [16, с. 4].

Культовые памятники представляют собой объекты культурного наследия, имеющие несомненную историческую и художественную ценность. Сегодня в Республике Бурятия на государственной охране находится 36 сохранившихся объектов культурного наследия религиозного назначения, из которых 6 объектов: Посольский Спасо-Преображенский монастырь, ансамбль Селенгинского Троицкого монастыря, Гусиноозерский дацан, Одигитриевский собор г. Улан-Удэ, Собор Троицы г. Кяхта, Церковь Воскресения г. Кяхта, являются объектами федерального значения.

Культовые памятники являются объектом исследовательского интереса представителей различных наук: история, культурология, архитектура, искусствоведение и др. Среди современных достижений научных изысканий можно выделить Свод объектов культурного наследия Республики Бурятии (2010), который представляет собой одновременно справочное 
и источниковедческое издание, а также выполняет роль путеводителя по районам республики [16]. Как положительный пример эффрективной деятельности органов власти по популяризации объектов культурного наследия следует рассматривать фотоальбом «Храмы Бурятии» (2014) [18] и историко-краеведческое издание «Воскресенская церковь в Кяхте» (2017) [2]. Эти публикации, отличающиеся высоким уровнем полиграфического дизайна и качеством фотоматериалов, представляют собой попытку объективного отражения истории памятников. Широкому кругу читателей предоставлена уникальная возможность документально и визуально познакомиться с выдающимися памятниками культуры.

Наряду со специальными изданиями необходимо выделить труды современных исследователей по истории основания, судьбе и современному состоянию православных храмов: это работы В.К. Гурьянова [3], А.Д. Жалсараева [7], С.С. Жарниковой (Апанасенко) [1], Г.С. Митыповой [12], И.С Цыремпиловой [19; 20] и др. В качестве самостоятельного направления следует рассматривать многолетние инженерные обследования зданий, проводимые Деминым Э.В. и Пановым А.Б. Практическая значимость этих работ обусловлена необходимостью оценки технического состояния культовых сооружений для проведения антисейсмического усиления и реставрации зданий $[4 ; 5 ; 15]$.

Уникальным и старейшим памятником культовой архитектуры Бурятии является Посольский Спасо-Преображенский монастырь, который основали 12 монахов под предводительством игумена Феодосия и иеромонаха Макария в 1681 г. Обитель была основана на берегу оз. Байкал, на месте гибели русской посольской миссии в Монголию во главе с Ерофеем Заболоцким в 1650 г., что дало будущему монастырю название Посольский.

C 1773 г. стали возводить Спасо-Преображенский храм, который стал первой каменной постройкой в Забайкалье. Собор представлял собой выдающееся достижение архитектурной и технической мысли. Многие исследователи отмечают, что узорчатая обработка фасадов собора имеет сходство с декором Крестовоздвиженской церкви г. Иркутска, что говорит о единстве стиля сибирского барокко. В 1780 г. началось строительство Святых врат в «монастырь с главного подъезда» - со стороны Байкала и надвратной церкви, в 1812 г. была освящена еще одна каменная церковь во имя Святителя Николая Чудотворца [11, с. 126-128].

Качество постройки помогло монастырю устоять и в советские годы. Многочисленные попытки верующих в конце 1920-х - начале 1930-х гг. зарегистрировать религиозное общество встречали сопротивление со стороны органов власти: запрет на созыв собраний, проведение богослужений, отказ в регистрации служителя культа и т.п. Постановлением ЦИК БМАССР от 17 июня 1935 г. № 31 Посольский Спасо-Преображенский монастырь был закрыт [17, с. 55]. 
О периоде разрушений и утрат строений монастыря в советский период, использовании частично сохранившихся храмов под иные нужды кратко сообщалось в 1974 г. в паспорте памятника архитектуры. Для строительства Кабанской машинно-тракторной станции в 1936 г. были разобраны и использованы монастырские деревянные здания и сооружения, келии монахов, часовни над могилой строителя забайкальских монастырей Г.А. Осколкова и каменная ограда. Монастырь был принят на государственную охрану в соответствии с постановлением Совета Министров РСФСР № 1327 от 30 августа 1960 г. В 1961 г. здание было передано по охранному договору Посольскому детскому дому инвалидов.

В 1990-х гг. шефство над процессом восстановления архитектурного облика и функций монастыря взяло на себя Министерство иностранных дел России. С решения Священного Синода РПЦ от 19 апреля 2000 г. началось возрождение монастыря. С 2002 г. продолжаются реставрационные работы: было проведено инженерно-сейсмическое обследование сохранившихся строений, разработан проект реставрации монастыря. Результатом археологических раскопок (2000-2002 гг.) стало определение места захоронения погибших послов, где сегодня установлены кресты и построена часовня [10]. В 2002-2008 гг. велись работы по восстановлению Спасо-Преображенского собора, Святых (царских) врат, выходящих на Байкал, построены келейный корпус для братии и трапезная, восстановлен храм Святителя Николая Чудотворца и др.

Следующий объект федерального значения - Селенгинский Троицкий монастырь (1681 г.), являясь первым форпостом православия в Забайкалье, представлял собой своеобразный тип сибирского «стоячего» острога-крепости. В монастырский комплекс входило несколько церквей: храм Живоначальной Троицы, церковь во имя Святителя Николая Чудотворца, церковь во имя Всех Святых, надвратная церковь во имя св. Архистратига Михаила. Троицкий храм, построенный в стиле барокко, отличала многокрасочная гамма икон с золотыми окладами, богатство церковных атрибутов. На колокольне Никольской церкви имелись «часы боевые железные в станке с кампасом указательным». Это были первые башенные часы в Забайкалье. Всесвятская церковь была самой красивой из всех храмов монастыря. Иконостас в ней был сплошной «и по приличным местам вызолочен».

Монастырь в конце XVII-XVIII вв. являлся самым крупным оборонительным пунктом на территории края [7, с. 264]. В каждой из четырех башен монастыря было по три яруса («моста») в виде этажей с бойницами для «боя». Ограда была сложена из кирпича; при высоте 4 м она имела ширину 1 м. Высота кирпичной кладки башен (до купола) составляла 8,5 м, а общая высота башен до верхушки креста - 12 м. В настоящее время две южные башни и стена сохранились сравнительно хорошо. 
Троицко-Селенгинский монастырь на протяжении всей дореволюционной истории оставался центром миссионерской работы РПЦ, его настоятели в XVIII-XIX вв. возглавляли три духовных миссии. Он являлся крупнейшим хозяйственным центром в Забайкалье, ему принадлежали вотчины, заимки и рыбные угодья: оз. Котокель со всеми впадающими в него реками; мельница, сенные покосы и др.

Троицкая обитель продолжала действовать до 1920 г. История ее закрытия до конца не выяснена, известно лишь, что после ликвидации монастыря Свято-Троицкий храм какое-то время продолжал действовать как приходской и был закрыт только в конце 1920-х гг. После того как монастырь был разорен, там была размещена исправительная колония (до 1926 г.), затем ее сменила психиатрическая больница, остававшаяся де-фракто до 2005 г. Монастырь был принят на государственную охрану в соответствии с постановлением Совета Министров РСФСР № 1327 от 30 августа 1960 г. и получил статус памятника архитектуры.

В середине 1990-х гг. в с. Троицком был зарегистрирован православный приход, которому была передана часть надвратного Михайло-Архангельского храма. 25 декабря 2000 г. Президентом-Председателем Правительства РБ Л.В. Потаповым было подписано распоряжение о проведении мероприятий по освобождению исторического комплекса монастыря от занимавшей его психиатрической лечебницы. Решение это выполнялось на протяжении пяти лет. 26 декабря 2006 г. Священный Синод РПЦ принял решение о возрождении Свято-Троицкой Селенгинской обители. Силами духовенства и местного населения проводятся ремонтные и реставрационные работы Троицкого храма, надвратной Михайло-Архангельской церкви, южных башен ограды монастыря и др.

Ярким образцом сибирского барокко является кафедральный Одигитриевский Собор г. Улан-Удэ - первое каменное строение города. Возведение его началось в 1741 г. и продолжалось сорок четыре года. Строился храм на деньги местного купечества, которое «во искупление грехов - прошлых и будущих» жертвовало деньги не только на строительство собора, но и на его содержание. Собор сразу был признан кафедральным, т.е. главным храмом Верхнеудинского уезда. Объмно-пространственная композиция Собора является вариантом широко распространенной схемы, восходящей к культовому зодчеству Северо-Восточной Руси конца XVII в.: это трехчастный, симметричный так называемый «корабль», где все объекты слиты воедино и образуют плотный монолит.

По богатству иконостаса, церковной утвари и библиотеки Одигитриевский Собор не имел себе равных в Забайкалье. Царские врата, мебель для архиерейской кафедры, жертвенные столы - все было выполнено искусными мастерами из дуба, кипарисового дерева и березы. Главным художественно-декоративным украшением интерьеров собо- 
ра, не имевшим росписей, были золоченые резные иконостасы. В верхнем храме находился четырех-ярусный иконостас с восемью рядами икон [18, с. 42]. Собор являлся градообразующим центром, средоточием всей общественной и духовной жизни города. Отсюда начиналась главная улица города - Трактовая (позднее ул. Большая, современное название - ул. Ленина).

В советский период одним из первых в городе был закрыт Одигитриевский кафедральный Собор. Постановление Президиума ЦИК БМАССР от 6 сентября 1929 г. гласило: «В виду отказа Одигитриевского общества верующих от производства ремонта его, а также вследствие отсутствия других религиозных объединений, желающих принять названное здание культа в свое пользование, Президиум ЦИК постановил: а) здание религиозного культа - Одигитриевский кафедральный собор со всем его имуществом ликвидировать» [20, с. 225]. Первоначально в 1927 г. специально созданной комиссией было произведено обследование здания, которая выявила, что «в верхнем этаже храма по своду обнаружена огромная сквозная трещина и оказались порванными связи, соединяющие стены здания. Все это требует восстановительного ремонта, в настоящее же время при толчке угрожает обвалу». Уже после закрытия было принято решение о том, что здание может быть использовано только как временное хранилище (склад), а какой-либо ремонт или переустройство для его приспособления под общественно-культурные нужды ввиду ветхости видится нецелесообразным.

Судьба Одигитриевского храма в советский период представляет собой пример особой музеефикации, когда «музеефикация с целью максимального бережного сохранения памятника уступает место приспособлению под антирелигиозные, краеведческие и другие экспозиции.... Превращение архитектурного памятника в музей уступает место использованию памятника под музей» [9, с. 241]. Так, в 1933 г. из Верхнеудинского краеведческого музея был выделен антирелигиозный отдел, который затем становится самостоятельным музеем. Антирелигиозному музею в 1934 г. было передано здание Верхнеудинского Одигитриевского Собора как памятника 1-категории историко-архитектурного значения [19, с. 148]. В созданный музей поступило свыше 12 тыс. музейных предметов - бесценных памятников культуры, собранных в ходе многочисленных экспедиций по районам республики из разрушенных церквей и дацанов [13]. Это уникальные тибетские и монгольские рукописи, ксилографы, изобразительные материалы, буддийские танка, иконы, Острожская Библия Ивана Федорова, предметы культа, облачения священнослужителей и др., что сегодня составляет гордость собрания Национального музея Республики Бурятия.

В 1941 г. в связи с сокращением фринансирования Антирелигиозный музей был закрыт, а в 1946 г. был объединен с Центральным 
Бурят-Монгольским музеем. Впоследствии здание использовалось как фондохранилище музея истории Бурятии. Собор был принят на государственную охрану постановлением Совета Министров РСФСР № 1327 от 30 августа 1960 г. и является объектом культурного наследия федерального значения.

31 марта 1992 г. при Соборе был зарегистрирован православный приход и начаты работы по благоустройству прилегающей территории. 1 августа 1995 г. вышел указ Президента РБ Л.В. Потапова № 180 о поэтапной передаче собора под управление Русской Православной Церкви: «<...> Поддержать обращение православных христиан г. Улан-Удэ о поэтапном возвращении Свято-Одигитриевского собора Русской православной церкви законному владельцу» [8, с. 232]. В 1996 г. во время празднования Вознесения Господня были установлены 6 колоколов, в 1999 г. на колокольню водрузили крест. В 2000 г. центр Бурятского благочиния переместился из Свято-Троицкого храма в Одигитриевский Собор. Сегодня Одигитриевский Собор является резиденцией митрополита Улан-Удэнского и Бурятского, Высоко-преосвященнейшего Савватия.

Город Кяхта, входящий в Список исторических городов России, также богат объектами культурного наследия. Троицкий Собор и церковь Воскресения города являются уникальными памятниками истории и культуры.

Собор во имя Святой Троицы (1812-1817 гг.) был построен в стиле русского классицизма и являлся одним из крупных по размерам церковным зданием Забайкалья. Общая высота храма составляла 30 м, высота монументальной ярусной колокольни - 37,70 м, на ней было установлено 8 колоколов общим весом 509 пудов. Кроме того, на колокольне были установлены башенные часы с циферблатами «на две стороны, на восток и запад с боем». Храм и колокольню завершали позолоченные кресты с цепями и коронами. В 1854 г. московским отставным подполковником Дмитрием Бонческулом был прислан в дар список «чудотворной» иконы Божией Матери «Споручницы грешных». Икона, творящая «мироточение и чудесные исцеления», стала одной из святынь и широко известной за пределами Забайкалья [18, с. 119].

29 марта 1934 г. Собор был закрыт и передан на «культурные нужды», здесь разместили экспозиции музея, установили маятник Фуко. Несколько десятилетий здание пустовало. В 1960 г. Собор был включен в список памятников истории и культуры, но это не спасло его от бедствия, когда в 1963 г. деревянные купол, хоры, пол и крыша, частично перекрытия второго этажа сгорели во время пожара. Не сохранилась большая часть ограды, один из флигелей. После еще нескольких пожаров храм оказался заброшен, вокруг него был разбит городской парк. После передачи в 1997 г. здания РПЦ началось его восстановление. 
В настоящее время разработана проектно-сметная документация по реставрации Собора, на которую требуется свыше 200 млн р.

Образцовым храмом классицизма XIX в. считается Кяхтинская Воскресенская церковь, построенная в 1830-1838 гг. Композиция церкви сочетает в себе византийские традиции крестово-купольного храма с достижениями зодчества первой трети XIX в. Строение получилось нетипичным для сибирской архитектуры, и больше напоминало петербургские храмы-дворцы. Увенчанная шпилем высокая четырехъярусная колокольня, широкая трапезная и крестово-купольный храм с алтарем в восточной части расположены на единой оси. Храм имеет крестообразную в плане фрорму, причем пятиглавие значительно отдалено от колокольни.

В церкви имелся роскошный бронзовый иконостас с хрустальными колоннами (был выполнен в стиле Вестминстерского аббатства), серебряные царские двери, серебряные престол и жертвенники; громадное паникадило, усеянное цветными камнями; драгоценное евангелие и т.д. Английский миссионер Лэнсдел, путешествовавший по Сибири в 1879 г., с восхищением писал о великом духовном чуде Кяхты - Соборе, который слыл самым изящным в Восточной Сибири [6]. Путешественники называли его «застывшей музыкой в камне».

31 января 1930 г. Постановлением ЦИК Бурят-Монгольской АССР Воскресенская церковь была закрыта по причинам того, что «здание нуждается в ремонте... находящееся в нем культовое имущество находится в антисанитарном состоянии... ценное имущество не имеет надежного окарауливания, учитывая близость здания к границе с Монголией здание Воскресенского храма ликвидировать». В храме располагался склад спецторга.

В 1960 г. Воскресенская церковь была объявлена памятником республиканского (фредерального) значения, как и Троицкий Собор Кяхты. Несмотря на полученный статус, церковь долгое время была заброшенной, что стало причиной ее разрушения и разграбления. В 1970-е гг. были начаты реставрационные работы с целью дальнейшего использования здания для музея географических открытий Юго-Восточной Азии. 5 апреля 1996 г. Воскресенская церковь была передана в бессрочное и безвозмездное пользование РПЦ. В рамках празднования 350-летия добровольного вхождения Бурятии в состав Российского государства были выделены федеральные средства на реставрацию церкви. В сентябре 2011 г. храм был открыт после 40 лет реконструкции и ремонтных работ.

Таким образом, сохранившиеся и восстанавливаемые православные храмы Бурятии, имея большое значение в системе духовно-нравственного развития современного общества, сегодня выполняют особую роль в деле сохранения уникальной самобытности и культурного ландшафта региона. 


\section{Список использованной литературы и источников}

1. Апанасенко С. С. Православные монастыри как памятники культурного наследия: историко-культурологический анализ (на материалах Республики Бурятия) : автореф. дис. ... канд. культурол. наук / С. С. Апанасенко. - Улан-Удэ, 2011. $-20 \mathrm{c}$.

2. Воскресенская церковь в Кяхте / авт.-сост. Е. П. Михалева. - Улан-Удэ : Изд-во БНЦ СО РАН, 2017. - 280 с.

3. Гурьянов В. К. По Большой, Большой-Николаевской: из истории улиц Верхнеудинска: [историко-краеведческий очерк] / В. К. Гурьянов. - Улан-Удэ : БНЦ СО РАН, 1998. - 157 с.

4. Демин Э. В. Инженерное обследование сейсмичности зданий (сооружений) - памятников Троицкого и Селенгинского монастыря / Э. В. Демин, А. Б. Панов. - Улан-Удэ : Тип. ИП «Гармаев С.В.», 2002. - 172 с.

5. Демин Э. В. Инженерно-сейсмическое обследование Свято-Одигитриевского собора г. Улан-Удэ / Э. В. Демин, А. Б. Панов. -Улан-Удэ, 2003. - 257 с.

6. Дулов А. В. Православная церковь в Восточной Сибири XVII - начале XX вв. [Электронный ресурс] / А. В. Дулов, А. П. Санников // Иркутский МИОН. Режим доступа : http://mion.isu.ru/filearchive/mion_publcations/church/about.html

7. Жалсараев А. Д. Поселения, православные храмы, священнослужители Бурятии, XVII-XX столетий / А. Д. Жалсараев. - Улан-Удэ : Бурят. кн. изд-во, 2001. $-448 \mathrm{c}$.

8. Из истории религиозных конфессий Бурятии. XX век : сб. док. -Улан-Удэ : Респ. тип., 2001. - 292 с.

9. Каулен М. Е. Музеефикация историко-культурного наследия России / М. Е. Каулен. - М. : Этерна, 2012. - 432 с.

10. Лбова Л. В. Результаты археологической экспертизы территории Посольского Спасо-Преображенского монастыря (2002 г.) / Л. В. Лбова // Русская Православная Церковь в Сибири: история и современность. - Улан-Удэ : Изд-во Бурят. науч. центра СО РАН, 2003. - С. 78-84.

11. Минерт Л. К. Памятники архитектуры Бурятии / Л. К. Минерт. - Новосибирск : Наука, 1983. - 190 с.

12. Митыпова Г. С. Православие в истории и культуре Бурятии / Г. С. Митыпова. - Улан-Удэ : Изд-во ОАО «Республиканская типография», 2005. - 231 с.

13. Очирова Ц.-Х. В. Музею истории Бурятии им. М. Н. Хангалова - 80 лет. Хроника, события, личности / Ц.-Х. В. Очирова, Л. Ф. Левитина // Региональные музеи: настоящее и будущее : сб. ст. межрегион. науч.-практ. конф., г. Улан-Удэ, 21 ноября 2003 г. - Улан-Удэ : НоваПринт, 2003. - С. 7-17.

14. Памятники архитектуры и истории. Т. І. Свод объектов культурного наследия Республики Бурятия. - Улан-Удэ : Изд-во ОАО «Республиканская типография», 2010. - $328 \mathrm{c}$.

15. Панов А. Б. Инженерно-сейсмическое обследование зданий - памятников истории, архитектуры и культуры Республики Бурятия / А. Б. Панов, Д. Р. Дамдинова, Н.М.Ломова // Вестник Восточно-Сибирского государственного университета технологий и управления. - 2016. - № 3. - С. 18-23.

16. Свод объектов культурного наследия Республики Бурятия. Т. 1 : Памятники архитектуры и истории. -Улан-Удэ : Респ. тип., 2010. - 326 с.

17. Тиваненко А. В. «Храм опечатать, общину разогнать!». Из истории закрытия и разрушения Посольского Спасо-Преображенского монастыря в 1934 г. / 
А. В. Тиваненко // Деятельность Русской православной церкви в Забайкалье: история и современность: Ефремовские чтения - ІІ. - Улан-Удэ, 2005. - С. 49-56.

18. Храмы Бурятии: [фотоальбом]. - Улан-Удэ : Изд-во БНЦ СО РАН, 2014. $-172 \mathrm{c}$.

19. Цыремпилова И. С. Проблемы сохранения и использования православного культурного наследия в контексте государственно-церковных взаимоотношений в 1920-1930-х гг. (на материалах Байкальского региона) / И. С. Цыремпилова // Власть. - 2010. — № 7. - С. 144-150.

20. Цыремпилова И. С. Русская православная церковь и государство: история взаимоотношений в 1917-1930-е гг. (на материалах Байкальского региона) / И. С. Цыремпилова. - Улан-Удэ : ИПК ФГОУ ВПО ВСГАКИ, 2008. - 300 с.

\section{Информация об авторе}

Цыремпилова Ирина Семеновна - доктор исторических наук, профессор, и.о. проректора по научной работе, Восточно-Сибирский государственный институт культуры, 670031, г. Улан-Удэ, ул. Терешковой, 1; e-mail: irina161073@mail.ru

\section{Author}

Irina S. Tsyrempilova - Doctor of History, Professor, Acting Vice-rector in Charge of Scientific Work, East-Siberian State Institute of Culture, 1 Tereshkova St., 670031, Ulan-Ude, Russia; e-mail: irina161073@mail.ru 